DOI https://doi.org/10.30525/978-9934-26-007-0-17

\title{
ПРОВАДЖЕННЯ ЗА НОВОВИЯВЛЕНИМИ АБО ВИКЛЮЧНИМИ ОБСТАВИНАМИ У КРИМІНАЛЬНОМУ СУДОЧИНСТВІ УКРАЇНИ
}

\author{
Нор В. Т., Бобечко Н. Р.
}

\section{ВСТУП}

Провадження за нововиявленими або виключними обставинами, на зразок апеляційного та касаційного проваджень, становить собою елемент системи 3 оскарження й перевірки судових рішень у кримінальному судочинстві України. Незважаючи на важливе теоретичне значення i практичну затребуваність, цей спосіб перегляду судових рішень $€$ найменш дослідженим порівняно з означеними стадіями кримінального судочинства. Показовим $є$ той факт, що після кодифікації кримінально-процесуального законодавства України 2012 р. такій формі оскарження й перевірки судових рішень у кримінальному процесі досі не було присвячено жодного дослідження рівня монографії чи дисертації.

Та й з моменту набрання чинності новим КПК України стало очевидним, що уніфікація підстав для відновлення кримінального провадження не дає очікуваного ефекту з огляду на те, що нововиявлені обставини не охоплюють усього спектра випадків i, як наслідок, обмежує процесуальні можливості щодо їх виявлення, усунення та поновлення прав і законних інтересів особи, порушених неправосудними рішеннями. 3 огляду на це, 2017 р. у главі 34 КПК України з'явилася ще одна група обставин, яку законодавець назвав виключними. Утім така та деякі інші зміни не позбавили кримінально-процесуальну діяльність на цьому етапі від недоліків - до попередніх приєдналися нові.

У доктрині кримінального процесу та правозастосовній діяльності залишаються дискусійними, а подекуди й невирішеними чимало питань цього кримінально-процесуального провадження. Серед них - винятковість, факультативність провадження за нововиявленими або виключними обставинами, його резервне значення у виявленні та усуненні судових помилок порівняно 3 апеляційним та касаційним провадженнями, спрямованість лише на виправлення помилок із погляду факту, невідповідність цього кримінально-процесуального механізму принципу правової визначеності, структура провадження за нововиявленими або виключними обставинами, чи можуть бути об'єктами перевірки в цій стадії проміжні судові рішення та ухвали слідчих суддів, до якого суду належить подавати заяву про перегляд судового рішення за нововиявленими або виключними обставинами, якщо таке рішення вже було об'єктом судового контролю в апеляційному та касаційному порядках. 
3 огляду на вищевикладене виникла необхідність у комплексному аналізі проблемних моментів, пов'язаних із функціонуванням провадження за нововиявленими або виключними обставинами.

Метою цієї наукової статті $\epsilon$ дослідження теоретичних і прикладних проблем провадження за нововиявленими або виключними обставинами. Задля досягнення означеної мети перший параграф присвячений розкриттю правової природи та підстав для здійснення провадження за нововиявленими або виключними обставинами. У другому параграфі висвітлені процесуальні особливості, сформульовані поняття, завдання та окреслене значення цієї стадії кримінального провадження. Стаття містить відповіді на запитання, наскільки ефективною $є$ регламентація провадження за нововиявленими або виключними обставинами в кримінально-процесуальному законодавстві України, чи відповідає вона потребам правозастосовної діяльності, які доктринальні позиції з приводу суті такої стадії кримінального провадження потребують переосмислення або додаткового теоретичного обгрунтування, якими $є$ основні напрями вдосконалення нормативного регулювання такої форми оскарження й перевірки судових рішень.

\section{1. Правова природа та підстави для здійснення провадження} за нововиявленими або виключними обставинами

Забезпечення права на апеляційний перегляд справи та у визначених законом випадках - на касаційне оскарження судового рішення, Конституція України виділяє серед основних засад судочинства (п. 8 ч. 2 ст. 129). Конкретизуючи таку конституційну норму, КПК України регламентує порядок апеляційного та касаційного провадження.

Утім трапляються випадки, коли неправосудність судового рішення, що набрало законної сили, зумовлена існуванням таких обставин, які не були відомими суду на момент його ухвалення та які самі по собі або разом 3 уже встановленими фактами, ставлять під сумнів його законність, обгрунтованість та справедливість, як такого, що не відповідає об'єктивній дійсності. Такого роду обставини виокремлені законодавцем в окремі групи підстав для перевірки судових рішень, що пояснюється, насамперед, особливими способами засвідчення їх наявності.

За таких умов і виникла необхідність в існуванні ще однієї форми провадження з оскарження й перевірки судових рішень у кримінальному судочинстві України - провадження за нововиявленими обставинами.

Така форма оскарження й перевірки судових рішень $\epsilon$ компромісним вирішенням конфлікту двох концептуальних підходів - необхідності виправлення допущеної судової помилки, що демонструє ефективність 
системи кримінальної юстиції, та забезпечення стабільності й непохитності судового рішення, що набрало законної сили, тобто додержання принципу правової визначеності. Щоправда, для вітчизняного кримінальнопроцесуального законодавства таке твердження має декларативне значення, оскільки дві форми оскарження й перевірки судових рішень із трьох запроваджених дають змогу поставити під сумнів правосудність рішень, що набрали законної сили. На жаль, позиція українського законодавця з цього питання ще далека від досконалості та $є$ свідченням низки концептуальних недоліків судово-правової реформи, яка фактично не завершується в Україні .

Характеризуючи відновлення провадження за нововиявленими обставинами (Das Wiederaufnahmeverfahren), німецькі процесуалісти зазначають, що цей кримінально-процесуальний інститут служить матеріальній справедливості, яка дає змогу у виняткових випадках відступати від інтересу держави в забезпеченні правового порядку ${ }^{2}$. Законна сила судового рішення поступається, якщо додатково виявлені факти свідчать про його очевидну помилковість ${ }^{3}$.

Аналогічний підхід викладений в італійській кримінально-процесуальній доктрині - у провадженні за нововиявленими обставинами (Revisione) законодавець віддав перевагу справедливості над правовою визначеністю ${ }^{4}$.

Звідси провадження за нововиявленими обставинами невипадково належить до надзвичайних (екстраординарних) форм оскарження й перевірки судових рішень. Це твердження зумовлене ще й тим, що предметом цього провадження є питання про законність, обгрунтованість i справедливість судового рішення, насамперед щодо факту, з огляду на нововиявлені обставини, які існували на момент ухвалення цього рішення, але стали відомими тільки після набрання ним законної сили. Нововиявлені обставини неможливо виявити в матеріалах кримінального провадження, оскільки вони не відображені в них внаслідок того, що були невідомими суду під час судового розгляду. Такі обставини виявляють уже після набрання судовим рішенням законної сили і тому потребують самостійного дослідження. Їх наявність має бути встановлена вироком суду, що набрав законної сили, а за неможливості його ухвалення - постановою дізнавача, детектива Національного антикорупційного бюро України (далі - НАБУ), слідчого, прокурора про закриття кримінального провадження, ухвалою

\footnotetext{
${ }^{1}$ Бобечко Н.Р. Суть, завдання, значення та процесуальні особливості провадження за нововиявленими обставинами за КПК України. Юридичний науковий електронний журнал. 2015. № 1. С. 194.

${ }^{2}$ Klaus Haller, Klaus Conzen. Das Strafverfahren. 6, neu bearbeitete und erweiterte Auflage. München: C.F. Müller, 2011. S. 513.

${ }^{3}$ Claus Roxin, Bernd Schünemann. Strafverfahrensrecht. 27, neu bearbeitete Auflage. München: C.H. Beck, 2012. S. 488.

${ }^{4}$ Paolo Tonini. Manuale Di Procedura Penale. Quindicesima edizione. Milano: Giuffrè Editore, 2014. P. 961.
} 
суду про закриття кримінального провадження і звільнення від кримінальної відповідальності, ухвалою суду про застосування примусових заходів виховного чи медичного характеру (пп. 1, 4 ч. 2 ст. 459 КПК України).

Запровадження у 90-х роках XX ст. нового, попередньо невідомого вітчизняній правовій системі інституту конституційної юрисдикції, а також приєднання України до системи захисту прав та свобод людини, імплементація в національне законодавство положень Конвенції про захист прав людини й основоположних свобод у поєднанні з визнанням юрисдикції Європейського суду з прав людини (далі - ЄСПЛ) змусило законодавця розширити перелік підстав для відновлення провадження та включити до нього нові підстави. Підстави, про які йдеться, пов'язані з рішеннями Конституційного Суду України (далі - КСУ) та ЄСПЛ, що покликані виконувати щодо судових рішень, які набрали законної сили, реституційну роль (пп. 1, 2 ч. 3 ст. 459 КПК України).

На відміну від обставин, передбачених пп. 1, 4 ч. 2 ст. 459 КПК України, «встановлена Конституційним Судом України неконституційність, конституційність закону, іншого правового акта чи їх окремого положення, застосованого судом при вирішення справи», «встановлення міжнародною судовою установою, юрисдикція якої визнана Україною, порушення Україною міжнародних зобов'язань при вирішенні даної справи судом» як підстави для здійснення кримінального провадження за виключними обставинами, не існували під час розгляду кримінального провадження, а з'явилися після ухвалення судового рішення та набрання ним законної сили. Такі підстави не свідчать про допущення судової помилки фактичного характеру, натомість вказують на помилку з огляду на невідповідність правового регулювання порядку кримінального провадження та (або) судового правозастосування Конституції України, Конвенції про захист прав людини й основоположних свобод чи Міжнародного пакту про громадянські та політичні права. Суд, ухвалюючи рішення, не знав, що правова норма, яку він застосував, його правозастосовна діяльність у кримінальному провадженні повністю або частково не відповідають Конституції України, Конвенції про захист прав людини й основоположних свобод чи Міжнародного пакту про громадянські та політичні права. Законодавець об'єднав ці обставини в одну групу, назвавши їх виключними.

Водночас у доктрині вітчизняного кримінального процесу звернено увагу на невідповідність такої назви суті обставин, викладених у ч. 3 ст. 459 КПК України ${ }^{5}$.

\footnotetext{
${ }^{5}$ Бобечко Н.Р. Новели кримінально-процесуального законодавства України в контексті забезпечення єдності судової практики. Часопис національного університету «Острозька академія». Серія «Право». 2018. № 1. С. 26.
} 
Подібною за правовою природою та способом засвідчення до вищеозначених є обставина, викладена у п. 3 ч. 2 ст. 459 КПК України, «скасування судового рішення, яке стало підставою для ухвалення вироку чи постанови, що належить переглянути». Така обставина також відкривається після ухвалення судового рішення і не має безпосереднього зв'язку з предметом доказування в кримінальному провадженні. Ще однією спільною ознакою аналізованих груп обставин $є$ спосіб їх встановлення. Наявність цих обставин засвідчується в рішенні вищої судової інстанції (п. 3 ч. 2 ст. 459 КПК України), рішенні КСУ (п. 1 ч. 3 ст. 459 КПК України), рішенні ЄСПЛ чи Комітету ООН із прав людини (п. 1 ч. 3 ст. 459 КПК України). До рішень суду вищого рівня належать вирок апеляційної інстанції, ухвала про скасування судового рішення і закриття кримінального провадження або ухвала про скасування судового рішення і призначення нового розгляду в суді першої інстанції, а також постанова касаційного суду про скасування судового рішення і закриття кримінального провадження або ухвала про скасування судового рішення і призначення нового розгляду в суді першої чи апеляційної інстанції. У зв'язку з цим обставина, зазначена у п. 3 ч. 2 ст. 459 КПК України, за логікою законодавчої термінології, має належати до виключних, а не до нововиявлених.

До слова, підстава, викладена у п. 3 ч. 2 ст. 459 КПК України, відома кримінально-процесуальному законодавству інших держав. Для прикладу, згідно $з$ п. 4 § 359 КПК Федеративної Республіки Німеччини однією з підстав для відновлення кримінального провадження за нововиявленими обставинами $\epsilon$ скасування цивільно-правового рішення, на якому грунтується вирок, іншим судовим рішенням, що набрало законної сили. Підстава подібного змісту передбачена й у п. b Art. 630 КПК Італійської Республіки ${ }^{7}$ Схожа підстава відома й КПК Естонської Республіки. Так, відповідно до п. 4 ст. 366 цього кодифікованого акта підставою для відновлення провадження в кримінальній справі у зв'язку з нововиявленими обставинами $\epsilon$ скасування іншого вироку або постанови суду, що стали підставою для ухвалення вироку чи постанови суду в кримінальній справі, в якій відновлюється провадження, якщо це могло потягти винесення виправдувального вироку в цій кримінальній справі або покращення становища засудженого ${ }^{8}$.

Водночас саме по собі скасування судового рішення, яке стало підставою для ухвалення вироку чи постанови, навряд чи може бути підставою для перевірки судових рішень за нововиявленими обставинами. Це можливе тоді, коли скасування судового рішення здійснюється в частині правильності

\footnotetext{
${ }^{6}$ Strafprozessordnung. URL: https://www.gesetze-im-internet.de/stpo/__359.html.

${ }^{7}$ Codice di procedura penale. URL: https://www.brocardi.it/codice-di-procedura-penale/libro-nono/titolo-iv/ art630.html.

${ }^{8}$ Kriminaalmenetluse seadustik (KrMS). URL: https://www.riigiteataja.ee/akt/782861.
} 
встановлення тих обставин, що були покладені в основу вироку (ухвали), а також за умови, що використання таких обставин вплинуло на правосудність такого вироку (ухвали). Так само незрозуміло, чому у п. 3 ч. 2 ст. 459 КПК України йдеться лише про скасування, але не про зміну судового рішення. Очевидно, що й зміна судового рішення може торкатися фактичних обставин кримінального провадження. Ще більший подив викликає законодавча вимога про встановлення вказаних обставин вироком суду, який набрав законної сили, а в разі неможливості його ухвалення - їх підтвердження матеріалами розслідування (ч. 3 ст. 459 КПК України). Адже у п. 3 ч. 2 ст. 459 КПК України не йдеться про вчинення кримінального правопорушення'. Тому регламентація аналізованої підстави потребує удосконалення.

Вітчизняне кримінально-процесуальне законодавство впродовж тривалого часу пов'язувало провадження за нововиявленими обставинами із вчиненням кримінального правопорушення кимось із суб' єктів кримінального процесу, що мало істотний вплив на правосудність судового рішення. Однак після внесених змін до КПК України Законом від 3 жовтня 2017 р., про вчинення кримінального правопорушення учасниками кримінально-процесуальних відносин законодавець веде мову не тільки у п. 1 ч. 2, але й у п. 3 ч. 3 ст. 459 КПК України - встановлення вини судді у вчиненні кримінального правопорушення або зловживання слідчого, прокурора, слідчого судді чи суду під час кримінального провадження, внаслідок якого було ухвалено судове рішення. Доречно наголосити, що ч. 4 ст. 459 КПК України зобов'язує правозастосувача встановити такі обставини вироком суду, що набрав законної сили, а за неможливості його ухвалення підтвердити їх наявність постановою або ухвалою про закриття кримінального провадження, ухвалою про застосування примусових заходів медичного характеру. Аналогічний порядок засвідчення визначений і щодо обставин, передбачених у п. 1 ч. 2 ст. 459 КПК України. 3 огляду на це, викликає подив зарахування обставин, викладених у п. 3 ч. 3 ст. 459 КПК України, не до нововиявлених, а до виключних. Такі обставини існували ще в період здійснення судового провадження, але про них суд не знав, через те й не мав змоги їх урахувати, ухвалюючи судове рішення.

Законодавець слушно розмежовує підстави для провадження з оскарження й перевірки судових рішень, регламентовані у главі 34 КПК України, на дві групи. Нововиявлені обставини за природою, способом засвідчення, існуванням на момент ухвалення судового рішення, приналежністю до елементів предмета доказування в кримінальному провадженні, можуть бути

\footnotetext{
${ }^{9}$ Бобечко Н.Р. Нововиявлені обставини у кримінальному провадженні: поняття, ознаки, система. Науковий висновок Харківського державного університету. Серія «Юридичні науки». 2014. Т. 4. Вип. 6-2. C. 59-60.
} 
використані як в інтересах засудженого, так і не на його користь, істотно відрізняються від тих, які названі «виключними». Тому у главі 34 КПК України фактично передбачені два види кримінально-процесуальної діяльності щодо оскарження та перевірки судових рішень, які набрали законної сили, - провадження за нововиявленими обставинами та провадження за виключними обставинами.

\section{2. Поняття, процесуальні особливості, завдання і значення провадження за нововиявленими або виключними обставинами}

Обидва провадження мають як спільні, так і відмінні один від одного риси. Спільних ознак $є$ більше, проте відмінності вказують на специфіку конкретного кримінально-процесуального провадження в межах глави 34 КПК України.

Категорія «процесуальні особливості проваджень за нововиявленими та виключними обставинами» означає наявність таких положень, які істотно відрізняють провадження, регламентовані у главі 34 КПК України, від інших проваджень з оскарження й перевірки судових рішень (апеляційного та касаційного).

Процесуальні особливості провадження за нововиявленими або виключними обставинами проявляються в такому:

1) об'єктом їх перевірки є судові рішення, що набрали законної сили, та, які вже звернені до виконання чи, навіть, частково або повністю виконані;

2) такі провадження стосуються кожного основного чи підсумкового (остаточного) судового рішення (вироку, ухвали, постанови), що набрало законної сили, крім ухвал слідчого судді. Провадження за нововиявленими або виключними обставинами забезпечує перевірку основних судових рішень, а також ухвал, в яких вирішуються питання під час фактичного виконання рішення суду, за умови набрання ними законної сили.

Інакше кажучи, у зв'язку з нововиявленими або виключними обставинами можуть бути перевірені: обвинувальні та виправдувальні вироки, ухвали про закриття кримінального провадження, ухвали про закриття кримінального провадження і звільнення особи від кримінальної відповідальності, ухвали про застосування примусових заходів виховного чи медичного характеру, ухвали, в яких вирішені питання, пов'язані з виконанням судових рішень, а також вироки й ухвали судів апеляційної інстанції, постанови касаційного суду щодо вищезгаданих рішень судів;

3) наявність своєрідних підстав для здійснення провадження - нововиявлені та виключні обставини. Нововиявлені та виключні обставини не конкурують із підставами для оскарження й перевірки судових рішень в апеляційному та касаційному порядках, а навпаки, прямо виключають їх. 
Це підтверджується й виокремленням проваджень за нововиявленими або виключними обставинами в окрему форму проваджень 3 оскарження й перевірки судових рішень. Якщо останні ще не набрали законної сили, то для виявлення та встановлення нововиявлених чи виключних обставин жодних особливих процесуальних способів не вимагається, оскільки рішення перевіряється під кутом зору всіх підстав для скасування чи зміни судових рішень в апеляційному порядку.

3 іншого боку, нововиявлені обставини, як одна 3 груп підстав для перевірки судових рішень у кримінальному провадженні, будучи відмінними від усіх інших підстав для скасування або зміни судових рішень за формою, є подібними до них за змістом. Так, якщо вирок грунтується на завідомо неправдивих показаннях свідка і ця неправдивість виявилась після набрання ним законної сили (п. 1 ч. 2 ст. 459 КПК України), то матиме місце невідповідність висновків суду першої інстанції фактичним обставинам кримінального провадження (п. 2 ч. 1 ст. 409, 411 КПК України). Якщо виявлено інші обставини, що самі по собі або разом із раніше встановленими обставинами доводять незаконність, необгрунтованість i несправедливість судового рішення та не були відомі суду під час його ухвалення (п. 4 ч. 2 ст. 459 КПК України), то йтиметься про неповноту судового розгляду (п. 1 ч. 1 ст. 409,410 КПК України) $)^{10}$.

Водночас, згідно 3 ч. 5 ст. 459 КПК України, перегляд судових рішень за нововиявленими обставинами у разі прийняття нових законів, інших нормативно-правових актів, якими скасовані закони та інші нормативноправові акти, що діяли на час здійснення провадження, не допускається. Тобто зміна законодавства не може бути підставою для здійснення провадження за нововиявленими обставинами.

Особливий характер провадження за нововиявленими обставинами зумовлений наявністю спеціальних підстав для перевірки судових рішень, що набрали законної сили, з погляду факту. Понад те, виявлення обставин, які не були відомі суду на момент ухвалення судового рішення та які самі по собі або разом з уже достовірно встановленими фактами ставлять під сумнів правосудність такого рішення, порівняно з апеляційними та касаційними підставами трапляється зрідка. Нечасто з'ясовується й невідповідність правового регулювання та (або) судового правозастосування нормам Конституції України, Конвенції про захист прав людини і основоположних свобод та Міжнародному пакту про громадянські і політичні права;

\footnotetext{
10 Бобечко Н.Р. Нововиявлені обставини у кримінальному провадженні: поняття, ознаки, система. Науковий висновок Херсонського державного університету. Серія «Юридичні науки». 2014. Т. 4. Вип. 6-2. C. 55.
} 
4) перевірка за нововиявленими або виключними обставинами судового рішення тією ж судовою інстанцією (першою, апеляційною, касаційною), яка перша допустила помилку внаслідок незнання про існування таких обставин. У ст. 460, ч. 1 ст. 463 КПК України зазначено про можливість перевірки судового рішення у зв'язку з нововиявленими або виключними обставинами лише судовими інстанціями. Згідно 3 чч. 1-3 ст. 33 КПК України передбачено три судові інстанції - першу, апеляційну та касаційну.

Водночас ч. 4 ст. 33 КПК України встановлює, що кримінальне провадження за нововиявленими обставинами здійснюється судом, який ухвалив рішення, що переглядається. Натомість згідно з ч. 5 ст. 33 цієї ж статті кримінальне провадження за виключними обставинами здійснюється 3 підстав, визначених пп. 1, 3 ч. 3 ст. 459 КПК України, судом, який ухвалив рішення, що переглядається, а 3 підстави, визначеної п. 2 ч. 3 ст. 459 КПК України, - Великою Палатою Верховного Суду.

Беручи до уваги вищенаведені положення кримінально-процесуального законодавства України, під «судом, який ухвалив рішення, що переглядається〉 в аспекті провадження за нововиявленими або виключними обставинами варто розуміти суд першої, апеляційної чи касаційної інстанції;

5) можливість відкриття провадження за нововиявленими або виключними обставинами стосовно особи, щодо якої є вирок, який набрав законної сили, за тим самим обвинуваченням або ухвалою суду, постанова слідчого, прокурора про закриття кримінального провадження 3 тієї ж підстави. При цьому процесуальний статус такої особи під час провадження за нововиявленими обставинами залишається незмінним. Засуджений вважається засудженим, виправданий - виправданим;

6) у кримінальному провадженні немає такої судової інстанції, рішення якої вважалися б остаточними і не могли бути перевірені 3 огляду на нововиявлені або виключні обставини;

7) закріплення специфічних способів встановлення нововиявлених та виключних обставин: ухвалення та набрання законної сили обвинувальним вироком суду першої інстанції щодо діянь, передбачених у п. 1 ч. 2, п. 3 ч. 3 ст. 459 КПК України; постановлення та набрання законної сили ухвалою суду про закриття кримінального провадження і звільнення від кримінальної відповідальності, ухвалою суду про застосування примусових заходів виховного чи медичного характеру, за неможливості ухвалення обвинувального вироку щодо діянь, передбачених у п. 1 ч. 2, п. 3 ч. 3 ст. 459 КПК України, а також обставин, викладених у п. 4 ч. 2 ст. 459 КПК України; 
винесення постанови дізнавачем, детективом НАБУ, слідчим, прокурором про закриття кримінального провадження, за неможливості ухвалення обвинувального вироку щодо діянь, передбачених у п. 1 ч. 2, п. 3 ч. 3 ст. 459 КПК України, а також обставин, викладених у п. 4 ч. 2 ст. 459 КПК України; ухвалення та набрання законної сили рішенням суду вищої інстанції щодо обставини, зазначеної у п. 3 ч. 2 ст. 459 КПК України; оприлюднення рішення КСУ щодо обставини, викладеної у п. 1 ч. 3 ст. 459 КПК України; ухвалення та набрання законної сили рішенням суду вищої інстанції щодо обставини, зазначеної у п. 3 ч. 2 ст. 459 КПК України; набуття статусу остаточного рішенням ЄСПЛ щодо обставини, викладеної у п. 2 ч. 3 ст. 459 КПК України;

8) зарахування до дискреційних повноважень суду дослідження доказів із приводу обставин, що встановлені в судовому рішенні, яке $\epsilon$ об'єктом перевірки. Згідно з ч. 4 ст. 466 КПК України, суд має право не досліджувати докази щодо обставин, що встановлені в судовому рішенні, яке переглядається за нововиявленими або виключними обставинами, якщо вони не оспорюються.

Це положення є доволі спірним, оскільки з огляду на нововиявлені або виключні обставини такі докази можуть виявитись недостовірними. Докази, покладені в основу судового рішення, мають взаємозв'язок, тому суд повинен перевірити вплив нововиявленої або виключної обставини на кожен доказ зокрема і на усю сукупність доказів загалом. Крім того, рішення, про яке йдеться у ч. 4 ст. 466 КПК України, суд може прийняти лише за згоди учасників судового провадження ${ }^{11}$;

9) неможливість зміни, а також скасування із закриттям кримінального провадження судового рішення, що було об'єктом перевірки, за наслідками провадження за нововиявленими або виключними обставинами. Відповідно до ч. 1 ст. 467 КПК України суд має право скасувати вирок чи ухвалу і ухвалити новий вирок чи постановити ухвалу або залишити заяву про перегляд судового рішення за нововиявленими або виключними обставинами без задоволення. У процесі ухвалення нового судового рішення суд користується повноваженнями суду відповідної інстанції. За результатами перегляду судового рішення за нововиявленими або виключними обставинами Верховний Суд може також скасувати судове рішення (судові рішення) повністю або частково і передати справу на новий розгляд до суду першої або апеляційної інстанції.

\footnotetext{
11 Нор В., Бобечко Н. Порядок провадження за нововиявленими або виключними обставинами у кримінальному судочинстві України: проблеми правового регулювання і правозастосування. Право Украӥни. 2018. № 8. С. 166.
} 
Основним аргументом у забороні внесення змін до судового рішення або його скасування 3 наступним закриттям кримінального провадження за нововиявленими обставинами $є$ те, що вони не були предметом розгляду судами першої чи апеляційної інстанції. Однак такий довід не видається переконливим. Суд апеляційної інстанції за певних умов вправі змінити або скасувати судове рішення на підставі нових доказів, які також не були предметом судового розгляду. То навіщо тоді відповідний суд позбавляти змоги вносити зміни в судове рішення та його скасовувати і закривати кримінальне провадження на основі нововиявлених обставин, якщо доказова інформація, яка підтверджує їх наявність, одержана набагато достовірнішим способом, а судове провадження відбувається за одними й тими ж правилами? Очевидно, що чинна законодавча регламентація цього питання далека від оптимальності ${ }^{12}$.

Отже, провадження за нововиявленими або виключними обставинами $є$ стадією кримінального судочинства, яка регламентує діяльність учасників судового провадження щодо оскарження підсумкових рішень судів першої, апеляційної та касаційної інстанцій, які набрали законної сили, розгляду визначеною кримінально-процесуальним законом судовою інстанцією матеріалів кримінального провадження під кутом зору належним чином встановлених обставин, невідомих суду під час судового провадження, або тих, які з'явились після його ухвалення, що вплинули або могли вплинути на законність, обгрунтованість та справедливість постановленого судового рішення.

До завдань проваджень за нововиявленими та виключними обставинами належать: а) здійснення судового контролю за діяльністю судів першої, апеляційної та касаційної інстанцій, насамперед, під кутом зору факту (error facti), а в окремих випадках - із погляду відповідності законодавчого регулювання та судового правозастосування (error iuris) Конституції України, Конвенції про захист прав людини й основоположних свобод та Міжнародному пакту про громадянські і політичні права та в разі встановлення наявності нововиявлених або виключних обставин - узгодити оскаржене судове рішення 3 іншим судовим рішенням суду загальної юрисдикції, КСУ, ССПЛ чи підсумковими актами органів досудового розслідування; б) захист правосудних судових рішень, що набрали законної сили, від їх необгрунтованої, безпідставної зміни чи скасування.

У доктрині кримінального процесу поширеним $є$ погляд, що провадження за нововиявленими обставинами має резервне значення та використо-

\footnotetext{
12 Нор В., Бобечко Н. Порядок провадження за нововиявленими або виключними обставинами у кримінальному судочинстві України: проблеми правового регулювання і правозастосування. Право Украӥни. 2018. № 8. С. 167-168.
} 
вується, якщо вичерпані всі інші допустимі засоби процесуально-правового захисту ${ }^{13}$.

Варто зазначити, що в наведеній тезі відтворено правову позицію Конституційного Суду Російської Федерації, викладену у постановах від 2 лютого 1996 р. № 4-П ${ }^{14}$ та від 16 травня 2007 р. № 6-П ${ }^{15}$. Однак така позиція не видається обгрунтованою, оскільки Конституційний Суд Російської Федерації ототожнив судові помилки в застосуванні правових норм та судові помилки, зумовлені обставинами, про які суду не було відомо під час судового розгляду, що вплинуло або могло вплинути на правосудність ухваленого ним рішення. Провадження за нововиявленими обставинами, будучи самостійною формою оскарження й перевірки судових рішень, жодним чином не підміняє апеляційного та касаційного провадження, не є їхнім продовженням, відбувається не замість них, а за наявності для цього специфічних підстав. Тому цей кримінальнопроцесуальний інститут не може мати резервного значення щодо апеляційного та касаційного проваджень. Понад те, для початку провадження за нововиявленими обставинами зовсім не вимагається попередньої перевірки судового рішення судами апеляційної та касаційної інстанцій, тобто така умова, як вичерпання інших засобів процесуального захисту, відсутня. Насамкінець, наведений підхід нівелює дію принципу правової визначеності, оскільки для засудженого та виправданого навіть після апеляційного та касаційного провадження залишатиметься загроза погіршення становища внаслідок виявлення нових обставин, зумовлених однобічністю та неповнотою доказування.

13 Беднарська В.М. Перегляд судових рішень за нововиявленими обставинами в кримінальному судочинстві : автореф. дис. ... канд. юрид. наук : 12.00 .09 «Кримінальний процесс та криміналістика, судова експертиза; оперативно-розшукова діяльність» / Академія адвокатури України. Київ, 2007. С. 2.

Собенин А.А. Механизм проверки правосудности судебных решений ввиду новых или вновь открывшихся обстоятельств по уголовному делу : автореф. дис. ... канд. юрид. наук : 12.00 .09 «Уголовный процесс; криминалистика и судебная экспертиза; оперативно-розыскная деятельность» / Московская государственная юридическая академия. Москва, 2007. С. 9-10.

Баскакова В.Е. Возобновление производства по уголовному делу ввиду новых обстоятельств (вопросы теории и практики) : автореф. дис. ... канд. юрид. наук : 12.00.09 «Уголовный процесс, криминалистика и судебная экспертиза; оперативно-розыскная деятельность» / Казанский государственный университет. Екатеринбург, 2009. С. 16.

Балакшин В.С. «Новые» или «вновь возникшие» обстоятельства. Государство и право. 2011. № 2. С. 56.

${ }^{14}$ По делу о проверке конституционности пункта 5 части второй статьи 371, части третьей статьи 374 и пункта 4 части второй статьи 384 Уголовно-процессуального кодекса РСФСР в связи с жалобами граждан К.М. Кульнева, В.С. Лалуева, Ю.В. Лукашова и И.П. Серебренникова : Постановление Конституционного Суда РФ от 02.02.1996 N 4-П. URL: http://www.consultant.ru/document/cons_doc_LAW_9231/

15 По делу о проверке конституционности положений статей 237, 413 и 418 Уголовно-процессуального кодекса Российской Федерации в связи с запросом президиума Курганского областного суда : Постановление Конституционного Суда РФ от 16 мая 2007 г. N 6-П. URL: http://base.garant.ru/12153641/ 
До слова, у французькій доктрині кримінального процесу підкреслюється, що скористатися механізмом ревізії (La révision), аналогом вітчизняного провадження за нововиявленими обставинами неможливо за наявності правових підстав для виправлення судової помилки в межах інших форм оскарження та перевірки судових рішень ${ }^{16}$.

Австрійські процесуалісти категорично стверджують, що поновлення на тій підставі, що судове рішення, ухвалене за наявності процесуальних або матеріальних помилок, що оцінка доказів є помилковою або що вирок був занадто м'яким чи занадто суворим, виключається ${ }^{17}$.

Така позиція обгрунтована й у словацькій кримінально-процесуальній літературі. Метою відновлення провадження за нововиявленими обставинами не $\epsilon$ перевірка законності та обгрунтованості судового рішення та правильності кримінально-процесуальної діяльності, що йому передувала. У цьому провадженні суд не може досліджувати фактичні підстави судового рішення, ухваленого за наслідками попереднього судового розгляду, перевіряти дотримання порядку такого розгляду судом та учасниками процесу. У зв'язку з цим у провадженні за нововиявленими обставинами ревізійне начало не застосовують ${ }^{18}$.

Резюмуючи вищенаведені позиції, зазначимо, що помилки у встановленні фактичних обставин справи, хибна оцінка доказів, неправильне застосування кримінального та істотне порушення вимог кримінальнопроцесуального закону, несправедливе призначення заходів кримінальноправового впливу не можуть бути підставами для провадження за нововиявленими обставинами.

Отже, значення провадження за нововиявленими або виключними обставинами полягає в тому, що така форма оскарження й перевірки судових рішень $є$ додатковою гарантією правосуддя, захисту прав та законних інтересів учасників судового провадження, відновлення їхніх прав та свобод порівняно 3 основними - апеляційним та касаційним провадженням. У провадженні за нововиявленими або виключними обставинами закладений значний потенціал, однак практика застосування його норм традиційно невелика порівняно 3 апеляційним та касаційним провадженнями.

\footnotetext{
${ }^{16}$ Bernard Bouloc. Procédure pénale. 24-e édition. Paris: DALLOZ, 2014. P. 1024; Jean Pradel. Procédure pénale. 17-e édition. Paris: Éditions Cujas, 2013. P. 900-901; Michèle-Laure Rassat. Procédure pénale. 2-e édition. Paris: Ellipses Édition Marketing S.A., 2013. P. 737.

${ }^{17}$ Ernst E. Fabrizy. Kurzkommentar StPO 1975. 11, neu bearbeitete Auflage. Wien: Manz, 2011. S. 771.

${ }^{18}$ Ivor Jaroslav a kol. Trestné právo procesné. Druhé, doplnené a prepracované vydanie. Bratislava: Iura Edition, 2010. S. 765-766; Josef Čentéš a kol. Trestné právo procesné. Všeobecná a osobitná čast'. 2 vydanie. Šamorín: Heuréka, 2012. S. 659.
} 


\section{ВИСНОВКИ}

На відміну від апеляційного та касаційного проваджень, провадження, передбачене главою 34 КПК України, здійснюється з огляду на виявлення таких обставин, які або виникли після судового розгляду, або вже існували в період його розгляду, але не були відомі суду. При цьому до уваги беруться не будь-які обставини, а лише ті, що не дають змоги оцінювати ухвалені у кримінальному провадженні судові рішення як законні, обгрунтовані та справедливі. Тому провадження за нововиявленими або виключними обставинами породжене особливим характером судових помилок, для засвідчення та усунення яких воно й запроваджене. Такого роду правозастосовні помилки потребують докладно регламентованого порядку здійснення кримінально-процесуальної діяльності.

Провадження за нововиявленими або виключними обставинами $\epsilon$ запорукою балансу між загальнообов'язковістю судового рішення, що набрало законної сили, та його перевіркою у визначених випадках за встановленими правилами. Цей інститут відповідає як конституційним нормам, так і міжнародним зобов'язанням України щодо дії принципу правової визначеності у вітчизняній правовій системі. Провадження за нововиявленими або виключними обставинами забезпечує не усунення прогалин та (або) виправлення порушень, допущених під час досудового розслідування та судового провадження, а з'ясування фактів і обставин, що внаслідок об'єктивних і суб'єктивних причин раніше не були предметом дослідження в кримінальному провадженні. Така форма оскарження й перевірки судових рішень ставить остаточну крапку у вирішенні кримінального провадження по суті.

Правова регламентація підстав і порядку провадження за нововиявленими або виключними обставинами не позбавлена недоліків. Поряд із хибами концептуального характеру, мають місце й локальні прорахунки законодавця, здатні породити правову невизначеність. Неналежна теоретична розвідка провадження за нововиявленими або виключними обставинами та недоліки правової регламентації, як засвідчує судова практика, спричиняють ігнорування цієї форми оскарження й перевірки судових рішень. Цей кримінально-процесуальний механізм може і має використовуватися для усунення допущених під час кримінального судочинства порушень сам по собі, а не тоді, коли можливості їх виправлення в апеляційному та касаційному порядках виявилися вичерпаними. Тому щодо згаданих проваджень він не має вважатися резервним.

Отже, законодавче регулювання провадження за нововиявленими або виключними обставинами потребує комплексного та системного удосконалення. 


\section{АНОТАЦІЯ}

У статті аналізуються суть та зміст провадження за нововиявленими або виключними обставинами в кримінальному судочинстві України. За наслідками дослідження цього кримінально-процесуального механізму автори дійшли висновку, що вітчизняний законодавець слушно розмежовує дві групи підстав для здійснення провадження з оскарження й перевірки судових рішень, регламентоване у главі 34 КПК України. Акцентується увага на тому, що провадження за нововиявленими або виключними обставинами покликане не усувати недоліки досудового розслідування i судового розгляду кримінального провадження, здійснюючи резервну функцію у виявленні та виправленні судових помилок, а виконує власну роль у механізмі правового захисту. При цьому порядок кримінальнопроцесуальної діяльності в цій стадії значною мірою зумовлений підставами iii здійснення - нововиявленими або виключними обставинами. Наведені відмінності між обома групами цих обставин. Виокремлені процесуальні особливості провадження за нововиявленими або виключними обставинами, що відмежовують його від апеляційного та касаційного проваджень. Сформульовані завдання цієї стадії кримінального провадження та розкрито iii значення. Обгрунтовується необхідність удосконалення кримінальнопроцесуального законодавства, що регламентує провадження за нововиявленими або виключними обставинами.

\section{ЛІТЕРАТУРА}

1. Бобечко Н.Р. Суть, завдання, значення та процесуальні особливості провадження за нововиявленими обставинами за КПК України. Юридичний науковий електронний журнал. 2015. № 1. С. 193-197.

2. Klaus Haller, Klaus Conzen. Das Strafverfahren. 6, neu bearbeitete und erweiterte Auflage. München: C.F. Müller, 2011. 629 s.

3. Claus Roxin, Bernd Schünemann. Strafverfahrensrecht. 27, neu bearbeitete Auflage. München: C.H. Beck, 2012. 568 s.

4. Paolo Tonini. Manuale Di Procedura Penale. Quindicesima edizione. Milano: Giuffrè Editore, 2014. 1123 p.

5. Бобечко Н.Р. Новели кримінально-процесуального законодавства України в контексті забезпечення єдності судової практики. Часопис національного університету «Острозька академія». Серія «Право». 2018. № 1. C. 21-41.

6. Strafprozessordnung. URL: https://www.gesetze-im-internet.de/stpo/_ 359.html.

7. Codice di procedura penale. URL: https://www.brocardi.it/codice-diprocedura-penale/libro-nono/titolo-iv/art630.html. 
8. Kriminaalmenetluse seadustik (KrMS). URL: https://www.riigiteataja.ee/ akt/782861.

9. Бобечко Н.Р. Нововиявлені обставини у кримінальному провадженні: поняття, ознаки, система. Науковий висновок Харківського державного університету. Серія «Юридичні науки». 2014. Т. 4. Вип. 6-2. С. 55-61.

10. Нор В., Бобечко Н. Порядок провадження за нововиявленими або виключними обставинами у кримінальному судочинстві України: проблеми правового регулювання і правозастосування. Право Украӥни. 2018. № 8. C. $150-172$.

11. Беднарська В.М. Перегляд судових рішень за нововиявленими обставинами в кримінальному судочинстві : автореф. дис. ... канд. юрид. наук : 12.00.09 «Кримінальний процес та криміналістика, судова експертиза; оперативно-розшукова діяльність» / Академія адвокатури України. Київ, 2007. $23 \mathrm{c}$.

12. Собенин А.А. Механизм проверки правосудности судебных решений ввиду новых или вновь открывшихся обстоятельств по уголовному делу : автореф. дис. ... канд. юрид. наук : 12.00 .09 «Уголовный процесс; криминалистика и судебная экспертиза; оперативно-розыскная деятельность» / Московская государственная юридическая академия. Москва, 2007. $31 \mathrm{c}$.

13. Баскакова В.Е. Возобновление производства по уголовному делу ввиду новых обстоятельств (вопросы теории и практики) : автореф. дис. ... канд. юрид. наук : 12.00 .09 «Уголовный процесс, криминалистика и судебная экспертиза; оперативно-розыскная деятельность» / Казанский государственный университет. Екатеринбург, 2009. 24 с.

14. Балакшин В.С. «Новые» или «вновь возникшие» обстоятельства. Государство и право. 2011. № 2. С. 56-62.

15. По делу о проверке конституционности пункта 5 части второй статьи 371, части третьей статьи 374 и пункта 4 части второй статьи 384 Уголовно-процессуального кодекса РСФСР в связи с жалобами граждан К.М. Кульнева, В.С. Лалуева, Ю.В. Лукашова и И.П. Серебренникова : Постановление Конституционного Суда РФ от 02.02.1996 № 4-П. URL: http://www.consultant.ru/document/cons_doc_LAW_9231/.

16. По делу о проверке конституционности положений статей 237,413 и 418 Уголовно-процессуального кодекса Российской Федерации в связи с запросом президиума Курганского областного суда : Постановление Конституционного Суда РФ от 16 мая 2007 г. № 6-П. URL: http://base.garant.ru/12153641/.

17. Bernard Bouloc. Procédure pénale. 24-e édition. Paris : DALLOZ, 2014. 1126 p. 
18. Jean Pradel. Procédure pénale. 17-e édition. Paris : Éditions Cujas, 2013. $975 \mathrm{p}$.

19. Michèle-Laure Rassat. Procédure pénale. 2-e édition. Paris : Ellipses Édition Marketing S.A., 2013. 800 p.

20. Ernst E. Fabrizy. Kurzkommentar StPO 1975. 11, neu bearbeitete Auflage. Wien : Manz, 2011. $1310 \mathrm{~s}$.

21. Ivor Jaroslav a kol. Trestné právo procesné. Druhé, doplnené a prepracované vydanie. Bratislava : Iura Edition, 2010. 1049 s.

22. Josef Čentéš a kol. Trestné právo procesné. Všeobecná a osobitná čast'. 2 vydanie. Šamorín : Heuréka, 2012. 864 s.

\section{Information about authors:}

Nor V. T.,

Doctor of Judicial Sciences,

Head of the Department of Criminal Procedure and Criminalistics

Ivan Franko National University of Lviv

14, Sichovykh Striltsiv str., Lviv, 79000, Ukraine

Bobechko N. R.,

Doctor of Judicial Sciences,

Professor at the Department of Criminal Procedure and Criminalistics

Ivan Franko National University of Lviv

14, Sichovykh Striltsiv str., Lviv, 79000, Ukraine 